\section{JMLE \\ JOURNAL OF MEDIA LITERACY EDUCATION}

\title{
A local lens on global media literacy: Teaching media and the Arab world
}

\section{open AcCess}

Peer-reviewed article

Citation: Schmoll, K. (2021). A local lens on global media literacy: Teaching media and the Arab world. Journal of Media Literacy Education, 13(3), 62-74.

https://doi.org/10.23860/JMLE-202113-3-5

\section{Corresponding Author:}

Katharina Schmoll

k.schmoll@leeds.ac.uk

Copyright: $\odot 2021$ Author(s). This is an open access, peer-reviewed article published by Bepress and distributed under the terms of the Creative Commons Attribution License, which permits unrestricted use, distribution, and reproduction in any medium, provided the original author and source are credited. JMLE is the official journal of NAMLE.

Received: September 10, 2019

Accepted: September 15, 2020

Published: December 29, 2021

Data Availability Statement: All relevant data are within the paper and its Supporting Information files.

Competing Interests: The Author(s) declare(s) no conflict of interest.

\section{Editorial Board}

\author{
Katharina Schmoll \\ University of Leeds, UK
}

\begin{abstract}
The globalization and transnationalization of media use have facilitated access to voices from the Arab world. Students and teachers in Western higher education can make use of these voices within and outside the classroom to enhance students' knowledge of the region and challenge Eurocentric imaginations of the 'Other'. Yet to ensure students engage with these Arab sources in a meaningful way, media literacy is key. Drawing on and challenging a framework of global critical media literacy, this article argues that media literacy is grounded in time and space, meaning an effective teaching of global media literacy skills supposes an awareness of local media and power systems as well as communication cultures, and willingness to scrutinize one's own Eurocentric positionalities. In this endeavor, this article proposes to teach global media literacy the local way, here, pertaining to the Arab world through three distinct media case studies: influencers; women's activism; war and conflict.
\end{abstract}

Keywords: Arab media, Middle East, modernity, feminism, higher education.

\section{Journal of Media Literacy Education}

THE OFFICIAL PUBLICATION OF THE

National AsSOCiation for MEdia literacy Education (NAMLE)

Online at www.jmle.org 


\section{INTRODUCTION}

Stereotypical representations of (once) far-away cultures have a long history in Western media. The Arab world has particularly suffered from problematic representations. With the advent of Western modernity and colonialism in the $19^{\text {th }}$ and $20^{\text {th }}$ centuries, a pejorative Orientalist portrayal of Arabs as dangerous, backwards, and exotic, and Arab women as passive and oppressed emerged that served to justify colonial endeavors (Said, 1978). These stereotypes did not fade with the decline of colonialism but have continued to inform media images in popular culture and current affairs. As Ella Shohat and Robert Stam (1994) argued in their seminal work Unthinking Eurocentrism, such media representations cannot be apprehended outside the West's continued 'Eurocentric legacy', meaning a tendency to see and judge the world from a "single privileged point" (p. 2). To Shohat and Stam, Eurocentrism remains "embedded in everyday life, so pervasive, that it often goes unnoticed" (p. 1), spread through media, popular culture and education.

However, thanks to the rise of satellite TV and web 2.0 technologies, citizens in the West do not have to solely rely any longer on Western media representations but can directly access voices from the Arab world, allowing for more nuanced insights into the region. This notwithstanding, it takes appropriate media literacy skills to leave the problematic Eurocentric legacy behind and to become globally minded, informed and responsible citizens. Importantly, rather than only fostering what has been called global critical media literacy, aiming to spur reflection on self-positionality and Western cultural and economic hegemonies (Harshman, 2018), local media literacy is crucial to navigate region-specific mediascapes meaningfully. Indeed, this article argues that media literacy skills are grounded in time and space, with there being no fixed, single set of skills that allows one to become truly literate on a global scale.

Western higher education is predestined to take up the role in fostering such local media literacy, considering it is mostly young 'digital natives' who engage extensively with diverse global and transnational mediascapes. In this endeavor, this article proposes fostering local media literacy skills, here, pertaining to the Arab world ${ }^{1}$. Especially students and teachers concerned with global media, citizenship studies and/ or the contemporary Arab world can make use of local voices within and outside the classroom to enhance students' knowledge of the region. Notably, the article encourages teachers and students to integrate media case studies into the classroom and suggests ways of analyzing them. The types of media case studies the article proposes can be used both by "[t]eachers [who] may be uncertain about how to bring issues related to peoples and cultures they are unfamiliar with into the classroom" (Watt, 2012, p. 32) as well as by those teachers familiar with the region but perhaps not experts regarding its diverse mediascapes.

To begin, the article reviews dominant approaches to media literacy, arguing that global media literacy supposes a combination of more general as well as local literacy skills, before providing crucial background information on Arab media and power systems as well as communication cultures. On this basis and the author's experiences with teaching a UK-based MAlevel university course related to mediated cultures in the Arab world, the article proposes three media case study categories - influencers and modernity; women's activism and feminism; war and conflict - that teachers can use to facilitate students' mediated encounters with the region.

\section{APPROACHES TO MEDIA LITERACY}

\section{Traditional and critical approaches}

While there is no single definition, 'media literacy' has commonly been defined as "the ability to access, analyze, evaluate and create messages across a variety of contexts" (Livingstone, 2004, n.p.). Particularly the aspects of analysis and evaluation can be considered as the core of media literacy as "[t]here is little point in access or analysis without judgement" (Livingstone 2004, p.19). Importantly, the goal of analysis, evaluation and judgement depends on the approach one takes to the notion of media literacy.

In a simplified manner, media literacy can be categorized into two approaches: traditional/hierarchical and critical (Livingstone 2004). As Sonia Livingstone convincingly outlined, the 'traditional/hierarchical' approach centers upon a "discrimination of good from bad, authoritative from

\footnotetext{
${ }^{1}$ Here, I refer to the Arab world as countries of the Middle East and North Africa with large Arab populations and where Arabic is widely spoken and understood.
} 
unauthorised, information and communication" - in short, it is interested in objective truth; whereas the more recent 'critical approach' aims to "promote a democratised, diverse, anti-elitist approach to [...] representations" (Livingstone, 2004, p. 19), linking the production, circulation and consumption of information to power struggles. Borrowing from and building on cultural and audience studies, this critical approach then encourages one to analyze "relationships between media and audiences, information, and power" (Kellner \& Share, 2007, n.p.). Building on Stuart Hall (1980) and Ian Ang (2002), Kellner and Share have suggested that:

critical media literacy brings an understanding of ideology, power, and domination that challenges relativist and apolitical notions of most media education in order to guide teachers and students in their explorations of how power and information are always linked. This approach embraces the notion of the audience as active in the process of making meaning [...] (Kellner \& Share, 2007, n.p.).

Importantly then, this critical approach to media literacy moves away from reflecting primarily on objective truths of media messages and instead enters the arena of power politics. Rather than aiming at skills which allow distinguishing real news from fake news, and information from propaganda, this approach suggests that in order to be truly media literate, an awareness of power relations and subjectivity is indispensable to engage meaningfully with media texts. Concretely, audiences are encouraged to ask whose voices we hear, and whose voices are marginalized, distorted or absent. It demands a recognition of one's own subjectivity and an awareness of the fact that audiences' media consumption is never neutral but implicates meaning making. Understanding audiences, and here students, as actively engaged in meaning making and message decoding rather than as passive consumers of information then allows for a dynamic understanding of media literacy skills acquisition as a social practice (Luke \& Freebody, 1999) which can be realized in the classroom. Notably, it encourages a media literacy education centered upon civic awareness and responsibility.

Acknowledging power relations, inequalities and subjectivity as an inherent part of media literacy education is particularly pertinent regarding education about the so-called Global South and the West's continued 'Eurocentric legacy' (Shohat \& Stam, 1994, p. 1). Remaining embedded in everyday life through general culture and media representations, Eurocentric perspectives continue to shape the ways in which we imagine, analyze and judge non-Western cultures. As such, challenging Eurocentrism through education, fostering global media literacy skills is key to support students in becoming globally minded and responsible citizens that engage with non-Western cultures and citizens respectfully on equal terms and in an informed manner. Here, importantly, 'decentering Europe' does not mean a disregard of Western cultures and civilizational achievements but encouraging one to critically reflect upon how Western hegemonies might influence positionalities and stereotypes about 'the Other' (Said, 1978).

\section{Teaching global (critical) media literacy the local way}

In the context of global citizenship education, Harshman (2018) has suggested envisioning global critical media literacy as an awareness of global power structures and inequalities, and decentering Eurocentric perspectives in favor of diverse local, marginalized voices from the Global South.

Discussing how films can be meaningfully integrated in the classroom to provide alternative perspectives and nuanced insights into cultures other than one's own, he proposed a practical framework called the 'six C's' which "global educators can employ when they teach critical thinking skills related to global issues and media consumption" (Harshman, 2018, p.108). Focusing on the dimensions 'capitalism', 'citizenship', 'colonialism', 'conflict', and 'conscientious consumerism', the framework encourages students to reflect on Western cultural and economic hegemonies, one's own privileges and global inequalities, as well as common demeaning processes of 'Othering' in Western films; the framework similarly encourages teachers and students to question their own media consumption preferences for information and entertainment and to diversify the sources of their media consumption so as to give space and voice to indigenous, marginalized voices and perspectives.

Importantly though, this article argues, encouraging students to use a more diverse range of sources for information and entertainment and to acknowledge alternative voices and viewpoints only constitutes a first step in creating globally aware, informed citizens. The second important step is region-specific knowledge. While global critical media literacy, for instance as taught through the 'six C's', enhances students' awareness of power structures, privilege and positionality, it is critical to appreciate that capitalism, 
colonialism, modernity and globalization have not affected all cultures and regions in the same way. Similarly, Western prejudices towards various 'Others' differ; biases against Arab Muslim women or Black men, for instance, have different historical origins and thus need to be confronted with different sets of knowledge. As such, in addition to more general media literacy skills, teachers should foster students' regionspecific, local media literacy.

This can be accomplished, the article suggests, by integrating media case studies into the classroom, using them as a basis to foster region-specific knowledge. While discussing selected films in the classroom is meaningful, teachers should be mindful that students increasingly use diverse media formats and platforms including social media - outside the classroom to inform themselves about events and cultures around the globe, being "bombarded daily with a ceaseless barrage of media messages" (Sperry, 2006, p.37). With this in mind, it is vital to provide students with skills that enable them to meaningfully navigate diverse non-Western mediascapes on their own, all of which are implicated in specific regional power systems and cultural modes of communication. Becoming truly literate, this article argues, necessitates at least basic knowledge of regionspecific media, communication and power dynamics as well as willingness to scrutinize one's own positionalities and subjectivities shaped by Western modernity.

Lastly, in what has been called a post-truth era, the article suggests teachers cannot afford to neglect traditional/ hierarchical media literacy skills. Particularly in the context of war, conflict and propaganda, such as the Syrian civil war, teachers need to resist the postmodernist trend to predominantly investigate subjectivities, but equally engage students in a more 'hierarchical/traditional' discussion on objective truth and falsehood.

\section{MEDIA, POWER AND THE ARAB WORLD}

The globalization and transnationalization of media use, namely the rise of satellite TV and the Internet have facilitated access to voices from the Arab world. As a result, not only Western but increasingly indigenous media (re)presentations of the region shape students' understanding of the Arab world. This development facilitates education about and with the Arab world but comes with its own set of challenges. While students from the West are increasingly 'digital natives', they are not necessarily capable of critically analyzing and evaluating mediated voices from the Arab world unless they know Arab media systems, regimes of truth and power, education and Internet penetration rates, as well as gendered and linguistic dimensions of marginalization.

To ensure students learn to engage with Arab media sources in a critical and meaningful way, teachers can facilitate the navigation of Arab mediascapes through the integration of case studies in the classroom and enhancing awareness of the specific characteristics of those mediascapes. The notion 'Arab mediascapes' is used here with caution but in lack of a more convincing alternative. The Arab world is a vast region, encompassing most countries in the Middle East and North Africa, and home to diverse cultures and traditions, society structures, histories, political and media systems. Indeed, as Sreberny (2000, p. 66) wrote, the region "reveals remarkable differentiation among almost any indicator one cares to choose". The notion Arab mediascapes, then, even in the plural, is a generalization. While it is beyond the scope of this article to discuss any intra-regional differences in depth, the notion highlights and is informed by widely shared commonalities such as specific modes of communication, encounters with colonialism and Western modernity, power structures and issues of agency and marginalization. Furthermore, the term mediascapes, as conceptualized by Arjun Appadurai (1996), puts a spotlight on cultural flows and wider processes of production, dissemination and consumption of media, allowing for a holistic analysis that centers upon dynamics and engagement with media as well as culture-specific modes of communication.

The following two sections thus primarily provide insights into such local media and communicational dynamics by outlining historical, cultural, political and digital aspects.

\section{Classical Arab-Islamic modes of communication and their modern disruptions}

Issues of access and language have long made it difficult for Western students to consume media texts from diverse sources around the world, including the Arab world. Yet the increasing circulation of Englishlanguage or subtitled media texts, which leave the sense and feelings of the original message intact, allows students who may not speak Arabic to access voices from the region more easily. However, while students may face fewer linguistic difficulties, they may still be lost in cultural translation. 
To facilitate the navigation of Arab mediascapes, an awareness of region-specific, culturally and historically grounded underpinnings of local modes of communication and their modern disruptions is useful. In the classroom, teachers can support students in grasping key cultural communication differences for instance by discussing Muhammed Ayish's communication model for the region (2003). Building upon Arab Islamic and pre-Islamic worldviews and values, Ayish (2003) proposed a classic and normative Arab-Islamic communication model. Sketching out four key continuums of the Arab-Islamic model, namely individualism-conformity, transcendentalismexistentialism, intuitive-rational processes, and hierarchical-egalitarian, Ayish highlights that some Arab communicative style aspects - namely, intuition, transcendentalism, hierarchy and the prevalence of oral over written communication - are not duly accounted for in dominant Western-centric models. Classical features that students may come across and should be particularly aware of in Arab media are intuition and transcendentalism. In overly simplified terms, this means students may encounter expressive communication styles and a use of language informed by and infused with Islamic terms and worldviews, challenging the paradigms of rationalism and secularism of Western modernity (see case study type \#1).

Similarly, students should understand how these classical Arab-Islamic modes of communication have been disrupted by colonialism, modernity, and globalization. Following the 1798 takeover of Egyptian Alexandria by Napoleon's troops, Western domination inevitably altered indigenous ways of being and performing, leaving its marks on Arab public communication modes until today. Ever since, there has been an enmeshment of Arab-Islamic and Western features in the Arab world, mirroring persistent identity struggles and lately, perhaps, an increasing symbiosis (Ayish, 2008, Ch. 4 and Ch. 6).

Those cultural communicative ambiguities also become sensible ${ }^{2}$ in Arab mediascapes. Students should be aware not only of the co-existence of languages and cultures in Arab media but also of code switching and mixing within and between publics. The striking differences in style and content of debates between the Qatari transnational TV channels Al Jazeera Arabic and English are a prominent case in point (see e.g., Pollock, 2011). Students should be aware that the West is presented with a different experience of Al Jazeera and window into the region: Al Jazeera English is less hierarchical, less 'intuitive', less sectarian and divisive than its Arabic counterpart.

Most importantly, with the rise of digital technologies, the region has also seen the rise of an Internet-based youth-driven public sphere (Ayish 2018; Zayani 2015). One of the striking features of the Arab world certainly is its youthfulness, with roughly half of its citizens being under the age of 25. As Zayani has written:

This sizable generation [...] has been shaped by a set of disparate constellations induced by the increasing interpenetration of the local, the regional, and the global with new defining vectors ranging from social modernization to commodified consumerism and from religious revivalism to a deeply fascinating cyberculture. (Zayani, 2015, p. 5)

Indeed, many of these youths are digital natives, showcasing their hybridized identities on platforms such as YouTube, Instagram and TikTok, effortlessly fusing local and global elements and revealing continued attachment to Arab-Islamic values (Ayish, 2018; see also case study type \#1).

In addition to specific cultural modes of communication, students should also be aware of how the encounter between East and West, the subsequent development of a modern Arab public sphere, as well as the more recent technological developments have affected power dynamics in Arab mediascapes.

From Arab state media to transnational satellite TV and the internet: Regimes of truth and power, agency, and continued marginalization in times of social media

Students wishing to understand contemporary Arab mediascapes and mediated voices should develop at least a basic understanding of the post-colonial and postArab Spring power dynamics in the region and how fueled by increasing globalization, technological advance and revolutionary spirit - they have affected media production, consumption and discourses.

In the early post-colonial decades of the $20^{\text {th }}$ century, modernization and state-building efforts in the Arab world led to the rise of ideological and authoritarian state media that grappled with liberation, identity and development issues. Participation and democracy were

\footnotetext{
${ }^{2}$ Here, I use the term 'sensible' similarly to Jacques Rancière (2004) as 'what can be apprehended by the senses.'
} 
perceived as either an impossible luxury or Western governing style, and ideological and cultural disorientation became a critical feature of the Arab public sphere (Ayish 2008, Ch. 4). Yet since the early 1990s, due to increased globalization, political pressures as well as the rise of satellite TV channels, such as the Qatari Al Jazeera, and later the Internet, blogging as well as citizenship journalism, the modern Arab mediated public sphere has witnessed a major shift resulting in a loss of power for ideological and authoritarian state media and respective discourses. Despite persistent authoritarian, paternalistic and sectarian political regimes, new media platforms, formats and participants, such as women and youth, have paved the way for the opening up of public expression and debates and thus more diverse mediascapes (Ayish, 2008, Ch. 6; Ayish, 2018; Lynch, 2006; Sakr, 2004; Zayani, 2015).

Certainly, these transformations do not represent a complete shift in existing power relations towards agency and inclusivity. The Arab uprisings occurred "within an authoritarian context marked by single party rule, absence of free elections, lack of meaningful citizenship participation, disregard for the rule of law, the absence of shared governance and the pervasiveness of corruption and nepotism" (Zayani 2016, pp. 30-31).

Nevertheless, the web 2.0 has allowed for more diverse ways of self-expression, resistance and mobilization. There is an increasing blending of offline and online, embodied and narrative everyday practices attempting to reclaim minds, hearts and spaces (Bayat, 2010; Kraidy, 2016; Zayani, 2015). Multiple, mediated and at times creative ways of civic and political agency are unfolding:

Recent developments - better access to communication platforms, more proficiency in using information and communication technologies, wide adoption of 2.0 web applications, high internet penetration rates, noticeable growth in social media usage, ubiquitous use of mobile technology, faster pace and cheaper cost for transferring information - have transformed how information is being produced and consumed, altering user habits, shaping citizen experiences, introducing new societal dynamics, and reshaping power configurations (Zayani, 2016, p. 30).

Thanks to satellite TV and the Internet, students can witness those 'new societal dynamics' and emerging

\footnotetext{
${ }^{3}$ This is not to fall into the trap of Orientalism and victim to the idea of passive, submissive Arabs. (Mediated) agency existed long before satellite TV and Internet as for instance writings on 'small media' in the Middle East illustrated (Sreberny-Mohammadi \& Mohammadi, 1994).
}

agencies $^{3}$ first-hand, which counter Western images of Arab mindsets as authoritarian, Arab women as submissive, and the youth as voiceless (see case study types \#1 and \#2).

At the same time, students are likely to come across continued and new lines of marginalization and power struggles in Arab mediascapes. At times these are easy to spot, for instance in the case of war-torn Syria and powerful national and international propaganda machines (Della Ratta, 2018; see also case study type \#3) but sometimes also in less noticeable ways. A decade ago, blogging was elitist, and few Arabs wrote or read blogs (Lynch, 2007). Since then, literacy, Internet penetration and user rates in the Arab world have increased dramatically but national and intranational differences remain stark. A seven-nation ${ }^{4}$ survey on media use in the Middle East by Northwestern University in Qatar (2017) showed that while in Lebanon, Qatar, Saudi-Arabia and the United Arab Emirates more than $90 \%$ of the survey participants ${ }^{5}$ used the Internet, only half of Egyptians and two thirds of Tunisians did. Rates were particularly low for noneducated and primary-educated participants - potentially mirroring an urban-rural divide as well as a gender gap. Also, while almost all Internet users declared to view, post or share content online according to the survey about half of the participants even stated that they posted messages or comments on social media at least once a day, this was very rarely the case for non-educated and primary-educated participants. Another noteworthy result of the survey is mirrored by language use: While Arabic has increased proportionally with Internet users, foreign languages remain subordinate with less than a third of uses being in English.

Surveys are limited by nature. Still, students should be aware that not only authoritarianism, power struggles and paternalism influence Arab media content. Additional factors such as education levels/class, language proficiency/use, urban-rural divides as well as gender may affect in more subtle ways whose voices students come across in social media. As such, it is vital teachers provide information about the region's specific media dynamics. Combined with more general traditional/hierarchical and (global) critical media literacy skills, this will allow students to become literate in the context of Arab mediascapes.

\footnotetext{
${ }^{4}$ Countries include Egypt, Jordan, Lebanon, Qatar, Saudi Arabia, Tunisia, and the United Arab Emirates.

${ }^{5}$ Figures for nationals only (excluding expats).
} 


\section{TEACHING ARAB MEDIA LITERACY}

A convenient and efficient way to enhance students' Arab media literacy is to analyze and evaluate media case studies from the Arab world in the classroom. Case studies can be YouTube or TikTok videos, TV clips, Instagram pictures, newspaper articles, Tweets from the region, etc. To be most effective, case studies should preferably be chosen by students based on media texts from media platforms they commonly use in their everyday lives. In line with Harshman's (2018, p. 113) conceptualization of global critical media literacy and 'conscientious consumerism" as "[critical selfreflection] on preferred sources of information and entertainment", teachers might also specifically encourage students to consume and explore content and self-(re)presentations by groups of people that have been marginalized and misrepresented in Western and/ or traditional Arab public spheres including media.

To ensure a meaningful and critical engagement with those texts, the following section loosely suggests three categories of case studies and ways in which teachers can direct students' analysis and evaluation of such case studies. The categories that the author proposes influencers and modernity; women's activism and feminism; war and conflict - have crystallized from the author's own teaching experience and her former students' suggestions for case studies.

More precisely, this typology of case studies is based on a UK-based MA university course the author taught on mediated cultures in the Arab world in 2017. Over the course of ten weeks, the author led three weekly groups of seminars, with each seminar complementing a theory-driven lecture. All seminar groups consisted of between 12-16 students from a wide variety of educational and geographic backgrounds. A minority of students identified as Arab, and had lived in the Arab world or were of Arab descent. For each seminar, a few students (as preparation prior to the seminar) had to pick a media case study, analyze and evaluate it (see Livingstone, 2004) through a distinct analytical lens loosely based on the week's lecture topic, and then present it in the classroom, serving as a basis to spur a wider discussion. While the lectures' theoretical lenses - such as public sphere, modernity, audiences, nation(alism), power and resistance, identity, and visual cultures - certainly influenced which case studies students chose, those lenses were broad enough to leave

${ }^{6}$ Questions based on Harshman (2018, p.113) and NAMLE's 'Core Principles of Media Literacy Education', see students considerable freedom in choosing their case studies. Also, several lenses such as 'modernity' seemed to spark interest to such an extent that students repeatedly applied them to various case studies independent of the week's actual lecture topic. As such, albeit potentially colored by the specific lecture topics as well as current affairs happening during the period of teaching, the case study types are hopefully useful in supporting a guided discussion in the classroom on major topics related to contemporary Arab mediascapes.

Importantly, while all of the three types of case studies - influencers and modernity; women's activism and feminism; war and conflict - require specific local media literacy skills, they also need to be complemented by more general literacy skills. While the first two categories demand a democratized, anti-elitist and globally-minded critical approach to media literacy that promotes reflection on power structures and selfpositionality (Harshman, 2018; Kellner \& Share, 2007; Livingstone, 2004), the latter category on war and violence necessitates a traditional approach to media literacy (Livingstone, 2004).

\section{Translating media literacy into practice: Case studies from and for the classroom}

Demanding to pay attention to and deconstruct power relations, a critical media literacy approach can sharpen students' consciousness and focus their attention on voices previously marginalized in Western and/or traditional Arab publics, such as those of youth and women. In particular, social media platforms such as YouTube, Instagram and Twitter allow access to diverse, intimate and everyday negotiations and performances of identity that students in the West may otherwise be excluded from. These self-representations can improve students' understanding of the region by fostering students' reflection on their own positionality.

To spur reflection and discussion among students on these issues through case studies, it is useful to translate the rather abstract approaches to media literacy into practical questions for the classroom. Here, in the context of critical media literacy and case study categories \#1 and \#2, students and teachers should analyze, discuss and evaluate questions ${ }^{6}$ such as: Whose voices are heard, neglected or silenced in the media, and why? What are the overt and hidden ideas, values, information? Which statuses and identities are Qs.pdf 
privileged or marginalized? How does a media text provide agency? How and why do I interpret what I see and hear in media in the way I do, and what do I learn about myself from a particular interpretation? With these questions in mind, the article turns to case studies \#1 and \#2.

\#1 Social Media Influencers: Capturing Moments of 'Modernity' and Agency. Short-form amateur and influencer social media content uploaded by Arabs in the region or the diaspora, often in a mix of English and Arabic, have gained wide popularity in the last decade. Saudi Arabia is now the world's biggest market for YouTube in per capita consumption (Radcliffe \& Lam, 2018; Dubai Press Club, 2018); and the Iraqi-American Huda Kattan (Huda Beauty) was listed number one on the first-ever Influencer Instagram Rich List (Hopper HQ, 2017). Social media influencers and celebrities such as the chef Manal Alalem ${ }^{7}$, the comedians Abdulaziz Baz (Bin Baz) ${ }^{8}$ and Darin Al Bayed ${ }^{9}$ as well as the lifestyle, fashion and beauty influencers $\mathrm{Njoud} \mathrm{Al}$ Shammari (Njoud) ${ }^{10}$, Dalal Al Doub (Dalalid) ${ }^{11}$ and Noha Nabil ${ }^{12}$, to name but a very few, can provide a window onto a young, hip, stylish and funny Arab world open to the world. Long marginalized in both regional and Western mass media, the mostly young men and women embody agency, give a glimpse of everyday normalcy beyond violence or terror, challenge Western assumptions of modernity and point to the possibility of a symbiosis of Western and Arab-Islamic communication modes and identities.

Teachers can use this content to engage students to rethink what it means to be modern and to challenge the idea that personal and civic agency is only to be found in Western secular, liberal public spheres. Since the $18^{\text {th }}$ century, modernity has served as a concept for the West to develop a certain model of society based on individualism, secularism, and democratic government (Mitchell 2000). While the concept originated in the West, it was proclaimed universal in time and space (see e.g., Lerner, 1958) although being nothing more than a "particular [autocentric] paradigm about a particular narrative of happiness" (Sabry, 2010, p. 12). Especially the public role of Islam in Arab societies has been under scrutiny in the West. As John Esposito has written:

\footnotetext{
${ }^{7}$ http://www.manalonline.com/

${ }^{8} \mathrm{https} / / /$ www.youtube.com/channel/UC79RWgVZMQa2VO ABDPPFvtA;

https://www.instagram.com/bin_baz/

${ }^{9} \mathrm{https}: / /$ www.youtube.com/channel/UCZFP20Y4KMr42fhQh

VGqi_g; https://www.instagram.com/darin00013/
}

The conventional wisdom that assumed the centrality of secularism in a modern state and viewed religion as only a private affair has been challenged in much of the Muslim world. The resurgence of Islam in Muslim politics and society has in fact signaled a "Retreat from the Secular Path". (Esposito, 2010, p.1)

In contrast to the often violent or oppressive Western representations, the Islam that Arab influencers portray, embody and perform in subtle or more overt ways is an opportunity for students to discuss and reflect upon their own imaginations and the biases of modernity, Muslims and Islam. Students and teachers can also discuss how young Arabs function as motors of change, challenging social and gendered norms as women confidently assert space in the public and comedians subvert stereotypical gender norms.

Additionally, teachers and students can also critically discuss whose voices they come across in (social) media in terms of class, education and lifestyle.

\#2 Class, Gender, and Women's Activism: Whose Voices do We listen to? The West has long held a fascination for Arab gender conceptualizations ever since a colonial gaze allowed insights into and explorations of the lives of Arabs. In the West, stereotypical images of the East as exotic and barbaric, and women as docile and submissive became widespread during colonialism, when portraying the East as the quintessential 'Other' (Said, 1978) served the colonial powers to justify their imperialist endeavors.

In the classroom, case studies on women and gender have perhaps been unsurprisingly among the most popular. Many examples of websites and social media messages that the author's former students wished to analyze in class centered around women's empowerment, feminist activism and development. Often, and with very good intentions to understand 'insight perspectives', students suggested media content whose contributors originated from and/or were based in the Arab world. Yet due to language barriers, the chosen media texts were often, at least partly, in English or French and often with a Western-leaning feminist outlook. Here, it is critical teachers engage students in reflecting upon whose voices from the region they are presented with in terms of class and gender ideology.

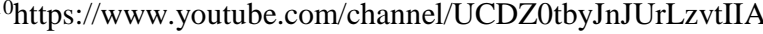

DLCg/; https://www.instagram.com/njoudsh1/

ww.instagram.com/dalalid/

https://www.youtube.com/user/dalalid/videos

${ }^{12} \mathrm{https}: / / \mathrm{www}$. youtube.com/user/da6wa/feed

https://www.instagram.com/nohastyleicon/ 
Feminism has long been criticized for its Eurocentricity. Chandra Talpade Mohanty (1988), for instance, has stressed that Western feminist discourses reinvigorated colonial universalisms of gender and instead promoted more complex and diverse feminist approaches that do not categorize women as a homogenous group with the same struggles and aims around the globe. Similarly, in postcolonial Arab societies, feminism has been regarded with suspicion and long remained elitist. More recently, however, a new type of Arab women's activism has emerged that differs from the traditional, secular middle and upperclass urban feminism in that it is more susceptible to Islamic gender ideals and mainly championed by 'ordinary' women. In a region-wide study on women's activism since the Arab uprisings, it has been observed that 'ordinary women', that is women "with no specific feminist knowledge and experience, [...] participated in the protests, [and] provided the impetus for shaping a new form of women's, or feminist, consciousness and practice different from the old elitist model of feminism" (Muhanna-Matar, 2014, p. 6):

They exercised their agency beyond their gender identity, calling for equal rights, human dignity and justice for both men and women, particularly marginalised social groups, without necessarily calling for cultural revolution against patriarchal religious/traditional practices (Muhanna-Matar, 2014, p. 6).

Often less well organized and internationally connected, working on the ground and reaching out to lower segments of society, and using Arabic rather than English or French, this women's activism has been less visible to the West than the more secular-elitist feminism. However, in wishing to understand and support Arab women's activism in greater depth, this non-elitist women's activism should be acknowledged, even though it may be less close to current Western gender ideals and struggles. While it is good that students bring feminist case studies to the classroom, they should be encouraged to discuss what kind of women's activism and gender conceptualizations they encounter in Arab mediascapes. Often, this may be an elitist, urban and internationally connected type of women's activism.

In her essay 'Can the Subaltern Speak?', Gayatri Chakravorty Spivak (1988) prominently interpreted the relationship between colonizers and colonized as 'white

\footnotetext{
13 Questions based on the NAMLE's 'Core Principles of Media Literacy Education', see https://namle.net/wpcontent/uploads/2020/06/NAMLE-Key-Qs.pdf
}

men saving brown women from brown men', drawing attention to questions of agency and voice in unequal power relations, such as 'who speaks to whom about what', and 'who is being talked about rather than being listened to'. Similarly, teachers can encourage students to critically reflect upon issues of voice and inclusivity, and whether they engage in a conversation in which Western and Arab secular feminists discuss about, rather than with, less elitist and feminist-oriented Arab women on what women's empowerment and gender justice mean.

\#3 Audio-Visual Media and Conflict: Truth, Players and Propaganda. While the two latter categories of case studies promoted a critical approach to media literacy, the last category, in contrast, demands a more traditional approach to media literacy. Whenever the Political comes directly into play, and particularly in times of war and conflict along sectarian, tribal and other dividing lines, applying a more traditional approach to media literacy is critical. This allows one to examine regimes of truths and power and to discriminate "good from bad, authoritative from unauthorised, information and communication" (Livingstone, 2004, p.19). In this context, discussing questions ${ }^{13}$ such as the following have proved useful: Who produced and financed the media text? Who is the target audience? Which messages are being communicated and which information is left out, and to whose benefit/detriment? Does the media text contain facts or opinions?

Indeed, in what has been called a post-truth era, teachers cannot afford to ignore the more traditional aspects of media literacy. However, even though students may be increasingly digital natives and techsavvy, refined propaganda and multiplied options for participation in globalized mediascapes affect the teaching of media literacy in ever new ways, as for instance the ongoing civil war in Syria illustrates. Propaganda has long been used as a weapon of war. But today's amount of video footage and technological advances make it difficult if not impossible even for professionals to grasp what is real, twisted, or staged. As such, while traditional media literacy education has enabled students not to easily accept what they see as 'truth', they may not be equipped with the skills to navigate present-day mediascapes congested with huge amounts of at times very technologically refined propaganda. 
A recent exhibition in the Imperial War Museum (IWM) in London, UK on the ongoing war in the Syria and respective media coverage ${ }^{14}$ pointedly asked whether the masses of available audio-visual footage has helped understanding of the war - or whether, on the contrary, it has sown confusion:

If Vietnam was the first conflict on television, Syria is the first on YouTube. The number of minutes uploaded exceeds the number of real-time minutes which have passed since the conflict began on Tuesday 15 March 2011. Every day, this number rises as the vicious conflict creeps onward, but does the quantity of material available mean we understand what is happening on the ground any better? ${ }^{15}$

How can students and teachers deal with the issue of propaganda and truth, and the sheer amount of video footage, in particular when confusion may be used as a systematic strategy by warring parties? In the best case, previously proposed questions can meaningfully guide the analysis and evaluation of media texts; and audiovisual material uploaded by amateurs on the ground can give students access to individual stories and narratives that they may be denied of in traditional media framings and coverage that is often humanly detached. However, another scenario is the incapability of "discrimination of good from bad" (Livingstone, 2004, p. 19). As a result of such a latter scenario, students may easily feel overwhelmed and become disengaged.

Instead, to nurture students' agency and interest, teachers can encourage new and creative pathways to media literacy. Research projects such as Forensic Architecture, for instance, propose new ways of providing evidence in times of war when various players deny responsibility for war atrocities, as could be witnessed after the bombings of two hospitals in the Syrian city of Idlib in February 2016. While Doctors Without Borders (MSF), which supported one of the hospitals, suspected that the strikes were carried out by Russian or Syrian state forces, the latter denied this. Forensic Architecture, however, which uses buildings, urban environments and media representations to meticulously reconstruct events ${ }^{16}$, concluded that both Russian and Syrian state forces are likely to have attacked the hospitals ${ }^{17}$.

Forensic Architecture's take on the bombings is but one example that illustrates how it remains possible and worth it to reflect on truth(s). Student-led group

\footnotetext{
${ }^{14}$ The 20172018 experimental immersive exhibition 'I Swear to Tell the Truth' was designed by the creative collective Anagram and commissioned by the IWM. http://weareanagram.co.uk/project/i-swear-to-tell-the-truth/
}

activities may be particularly expedient in fostering students' sense of agency, encouraging them to research or develop their own ideas on how we can crystallize truth in times of social media. Through a combination of long-valued practical questions related to traditional/hierarchical media literacy education, as outlined above, and creative new pathways, traditional media literacy education remains possible in contexts that demand such skills.

\section{CONCLUSION: TEACHING GLOBAL MEDIA LITERACY THE LOCAL WAY}

This article argued that media literacy is grounded in time and space. To become literate on a global scale, then, necessitates not only more general global critical and traditional/hierarchical but also local media literacy skills. Combined, they can challenge Eurocentrism (see Shohat \& Stam, 1994) and enable people to become globally-minded, informed and responsible citizens. On a practical level, the transnationalization and globalization of media use have allowed for diverse voices from around the globe and especially the Global South to become visible and audible to Western audiences; these can be used to foster such skills meaningfully. The article suggested that (Western) higher education is particularly predestined to transmit these skills through guided and informed discussions of local media case studies in the classroom.

More specifically, the article demonstrated that media literacy is grounded in time and space through the lens of the Arab world. Notably, based on the author's own experience with teaching a UK-based MA course on Arab mediated cultures, it proposed three distinct types of media case studies - influencers and modernity; women's activism and feminism; war and conflict which can support teachers in fostering Arab media literacy. First, the case studies have shown how Western modernity, ideals of secular public spaces as well as Western feminism may influence Western students' perceptions of and engagement with Arab mediascapes. With widely authoritarian and patriarchal Arab public spaces slowly opening up (Zayani, 2016), allowing greater voice and visibility to Arab women and youth long marginalized in traditional Arab and Western publics, students can constructively engage with these

\footnotetext{
15 https://www.iwm.org.uk/events/i-swear-to-tell-the-truth

16 https://www.forensic-architecture.org/project/

${ }^{17} \mathrm{https}$ //www.forensic-architecture.org/case/msf-supportedhospital/
} 
voices if they are willing to scrutinize their own positionalities and subjectivities. The continued presence of Arab-Islamic language and worldviews in Arab mediascapes despite early colonial encounters with the West challenge dominant Western communication cultures (Ayish, 2003, 2018) and can spur a discussion about what it really means to be 'modern' (Esposito, 2010; Mitchell, 2000; Sabry, 2010). Similarly, it may be fruitful to explore and discuss 'ordinary' Arab women's activism, which often differs from Western feminism and respective gender ideals (Muhanna-Matar, 2014; see also Mohanty, 1988; Spivak, 1988) and which is often less visible to Western students who, browsing digital platforms, are more likely to come across and engage with English-language secular, elitist, Western-leaning feminism. Strengthening awareness of how Western modernity, gender ideals, class, as well as local education and Internet penetration rates influence whose voices we hear and listen to is therefore critical. Fostering knowledge of local realities and students' awareness of their own positionalities and subjectivities - combined with more general (global) critical media literacy skills pertaining to issues of voice, power, privilege and marginalization (Harshman, 2018; Kellner \& Share, 2007; Livingstone, 2004) - can enable students to become informed, globally-minded and responsible citizens.

To become truly literate on a global scale, the article argued further, traditional/hierarchical media literacy is equally important. Aiming at differentiating between good and bad information (Livingstone, 2004), traditional literacy skills are crucial to become media literate in contexts of conflict, war and mediated propaganda. Having taken the Syrian civil war as an example, the article illustrated how refined present-day propaganda, used as a weapon of war to sow confusion, and the vast amount of digitally available (amateur) video footage of the Syrian war both necessitate and challenge the teaching of traditional media literacy. This considered, the article highlighted how questions related to traditional media literacy education around authenticity, propaganda, financial power, and audiences, need to be complemented by new creative pathways to foster media literacy and students' sense of agency.

While the article discussed more generalized power struggles in the Arab world and its mediascapes, it was beyond the article's scope to provide in-depth background information on the Syrian war. It was further beyond the article's scope to provide information about conflicts which gained more widespread prominence only after the author taught the MA course this article is based on, such as the Saudi-Iranian struggle for local supremacy. This again illustrates how media literacy skills are not only grounded in space but also in time. As such, while hopefully useful to teachers concerned with the contemporary Arab world, citizenship studies and/or global media, the three proposed case study categories and the author's take on these categories are necessarily incomplete and subject to change.

Future studies could therefore build on and extend these three case study types for the Arab world; more importantly though, the article hopes to inspire the development of frameworks to teach 'global media literacy the local way' for diverse regions and cultures around the globe, each of which are likely to be embedded in their own region-specific communication cultures, media systems, and power struggles.

To conclude, and coming back to critical media literacy, this article has engaged with global critical media literacy education from a Western viewpoint, aiming to challenge Eurocentric subjectivities. Yet immigration from the Global South and multiculturalism mean that positionalities and subjectivities as well as stereotypes towards the 'Other', including towards Arab men and women, may increasingly be informed by non-Western perspectives. As such, teachers may need to confront these in the classroom with a different set of skills, taking into consideration how diverse non-Western autocentrisms might have shaped perceptions of various 'Others'.

\section{REFERENCES}

Ang, I. (2002). On the Politics of Empirical Audience Research. In M. Durham \& D. Kellner (Eds.), Media and Cultural Studies Key Works (pp. 177-197). Blackwell Publishers.

Appadurai, A. (1996). Modernity at Large: Cultural Dimensions of Globalization. University of Minnesota Press.

Ayish, M. (2018). A Youth-Driven Virtual Civic Public Sphere for the Arab World. Javnost - The Public, 25(1-2), 66-74. https://doi.org/10.1080/13183222.2018.1418794

Ayish, M. (2008). The New Arab Public Sphere. Frank und Timme.

Ayish, M. (2003). Beyond Western-Oriented Communication Theories: A Normative Arab- 
Islamic Perspective. The Public, 10(2), 79-92. https://doi.org/10.1080/13183222.2003.11008829

Della Ratta, D. (2018). Shooting a Revolution. Visual Media and Warfare in Syria. Pluto Press.

Dubai Press Club (2018). Arab Media Outlook 20162018: Youth. Content. Digital Media. 5th Edition. http://www.dpc.ae/uploads/AMO-eng.pdf

Esposito, J. (2010). Rethinking Islam and Secularism. ARDA Guiding Paper Series. The Association of Religion Data Archives at The Pennsylvania State University.

http://www.thearda.com/rrh/papers/guidingpapers/E sposito.pdf

Hall, S. (1980). Encoding/Decoding. In S. Hall et al. (Eds.), Culture, Media, Language (pp. 128-138). Hutchinson.

Harshman, J. (2018). Developing Global Citizenship through Critical Media Literacy in the Social Studies. The Journal of Social Studies Research, 42(2), 107-117. https://doi.org/10.1016/j.jssr.2017.05.001

Hopper HQ (2017). Instagram Rich List 2017 - The Platform's Highest-Earners Revealed! https://www.hopperhq.com/blog/instagram-richlist-2017-platforms-highest-earners-revealed/

Kellner, D. \& Share, J. (2007). Critical Media Literacy is not an Option. Learning Inquiry, 1(1), 59-69. https://doi.org/10.1007/s11519-007-0004-2

Kraidy, M. (2016). The Naked Blogger of Cairo: Creative Insurgency in the Arab World. Harvard University Press.

Lerner, L. (1958). The Passing of Traditional Society: Modernizing the Middle East. Free Press.

Livingstone, S. (2004). What is Media Literacy? Intermedia, 32(3), 18-20.

Luke, A. \& Freebody, P. (1999). Further Notes on The Four Resources Model. Reading Online, 1-4. https://espace.library.uq.edu.au/view/UQ:145389

Lynch, M. (2007). Blogging the New Arab Public. Arab Media \& Society, n.p. https://www.arabmediasociety.com/blogging-thenew-arab-public/

Lynch, M. (2006). Voices of The New Arab Public. Iraq, al-Jazeera, and Middle East Politics Today. Columbia University Press.

Mitchell, T. (2000). The Stages of Modernity. In T. Mitchell (Ed.), Questions of Modernity (pp. 1-34). University of Minnesota Press.
Muhanna-Matar, A. (2014). New Trends of Women's Activism after The Arab Uprisings: Redefining Women's Leadership. LSE Middle East Centre Paper Series.

http://eprints.1se.ac.uk/68134/1/LEQSPaper16.pdf

Northwestern University in Qatar (2017). Media Use in The Middle East.

http://www.mideastmedia.org/survey/2017/interacti ve/social-media/who-use-the-following-socialmedia-platforms-facebook-whatsapp-twitterinstagram-snapchat-youtube-etc.html.

Pollock, D (2011). Aljazeera: One Organization, Two Messages. The Washington Institute. https://www.washingtoninstitute.org/policyanalysis/view/aljazeera-one-organization-twomessages

Radcliffe, D. \& Lam, A. (2018). Social Media in the Middle East: The Story of 2017; Key Developments, Stories and Research Findings. University of Oregon. http://hdl.handle.net/1794/23036.

Rancière, J. (2004). The Politics of Aesthetics. Continuum.

Sabry, T. (2010). Cultural Encounters in the Arab World: On Media, the Modern and the Everyday. I. B. Tauris.

Sakr, N. (Ed.). (2004). Women and Media in the Middle East: Power through Self-Expression. I. B. Tauris.

Shohat, E. \& R. Stam (1994). Unthinking Eurocentrism: Multiculturalism and the Media. Routledge.

Sreberny, A (2000). Television, Gender and Democratization in the Middle East. In J. Curran \& M. Park (Eds.), De-Westernizing Media Studies (pp. 63-78). Routledge.

Sreberny-Mohammadi, A. \& A. Mohammadi (1994). Small Media Big Revolution: Communication, Culture and the Iranian Revolution. University of Minnesota Press.

Sperry, C. (2006). Seeking Truth in the Social Studies Classroom: Media Literacy, Critical Thinking and Teaching about the Middle East. Social Education, 70(1), 37-43.

Spivak, G.C. (1988). Can the Subaltern Speak? In C. Nelson \& L. Grossberg (Eds.), Marxism and the Interpretation of Culture (pp. 271-313). Macmillan.

Watt, D. (2012). The Urgency of Visual Media Literacy in Our Post-9/11 World: Reading Images of Muslim Women in the Print News Media. JMLE. 4(1), 3243.

Zayani, M. (2016). On the Entangled Question of Media and Politics in the Middle East. In M. Zayani \& S. 
Mirgani (Eds.), Bullets and Bulletins: Media and Politics in the Rise of the Arab Uprisings (pp. 2343). Hurst Publishers.

Zayani, M. (2015). Networked Publics and Digital Contention: The Politics of Everyday Life in Tunisia. Oxford University Press. 